\title{
カルマンフィルターによる \\ 都市貯留関数モデルの実時間洪水流出予測特性 \\ REAL-TIME RUNOFF FORECASTING CHARACTERISTICS OF URBAN STORAGE FUNCTION MODEL USING KALMAN FILTER
}

\author{
高崎忠勝 1 河村明 2 ・天口英雄 3 ・石原成幸 4 \\ Tadakatsu TAKASAKI, Akira KAWAMURA, Hideo AMAGUCHI and Shigeyuki ISHIHARA \\ 1正会員 博(工) 東京都土木技術支援・人材育成センター（干136-0075 東京都江東区新砂一丁目 9-15） \\ 2正会員 工博 首都大学東京（干192-0397 東京都八王子市南大沢1丁目1） \\ 3 正会員 博(工) 首都大学東京（干192-0397 東京都八王子市南大沢1丁目1） \\ 4正会員 修(学) 東京都土木技術支援・人材育成センター（†136-0075 東京都江東区新砂一丁目9-15）
}

\begin{abstract}
The Kalman filter (KF) is a mathematical power tool that is used for real-time forecasting. In this paper, we implement KF on Urban Storage Function (USF) model which is a nonlinear lumped model considering urban runoff process. USF model using KF is applied to a virtual catchment where rainfallrunoff characteristics are known. The model parameters are updated with 1-minute river discharge data by $\mathrm{KF}$. The characteristics of real-time forecasting of the model using KF is discussed by comparison with the model using a particle filter. The results show that KF forecasted in a very short computation time with performs comparable to the particle filter.
\end{abstract}

Key Words : urban storage function model, kalman filter, particle filter, virtual catchment

\section{1. はじめに}

東京都内には地下鉄, 地下街, ビルや個人住宅の地下 室等の地下空間が多く存在しており，毎年，こうした地 下空間において浸水被害が発生している1). また，都市 域を流れる中小河川においては大雨時に極めて短時間に 増水するため, 河川溢水が生じた場合には地下空間への 浸水による人的被害の発生が危惧される。このため，早 期の水防活動や避難に資する都市中小河川の洪水予測が 期待されている.

実時間洪水予測が既に運用されている河川もあり，北 海道の事例ではカルマンフィルターを用いることで予測 精度の向上が図られている2 . また，近年では計算速度 の向上に伴い，粒子フィルターを導入した事例 ${ }^{3), 4}$ も報告 されている.

時系列フィルターの一種であるカルマンフィルターと 粒子フィルターを比較すると, 線形, ガウス型分布のカ ルマンフィルターに対して非線形, 非ガウス型分布の粒 子フィルターの方が高い予測精度を期待できる反面，計 算機資源の限られた環境下においては実時間処理におい て計算量が少ないカルマンフィルターが有利な場合があ る5). また, 計算にカルマンフィルターと粒子フィル
ターの双方を用いた事例(6)報告されており，これらの フィルターを適用した場合の計算量のみならず予測特性 の違いを明らかにすることによって，洪水予測の精度向 上を図ることが可能になると考えられる.

著者らは都市中小河川の洪水予測に適した特性を有す る都市貯留関数モデル (Urban Storage Function model : 以下，USFモデル） ${ }^{7)}$ を提案し，実流域への適用性やパ ラメータ特性について検討し，さらに，実時間予測にお ける粒子フィルターの特性について検証を行っている ${ }^{8), 9)}$. しかし，これまでにUSFモデルにカルマンフィルターの 適用は行われていない.

本論文は都市中小河川の実時間洪水予測の高精度化に 向けてカルマンフィルターを組み込んだUSFモデルの実 時間予測特性を明らかにすることを目的としている。ま ず，USFモデルによるカルマンフィルターの定式化を具 体的に示す. 定式化においてはカルマンフィルターに よって推定すべき状態量に1変数を加えることにより, 全ての未知パラメータを取り扱うことを可能にしている. 次に, 都市中小河川の洪水予測に適したカルマンフィル ターの設定を検討する。ここでは観測データに含まれる 各種誤差の影響を排除するため降雨流出特性が既知の仮 想流域を対象とする.さらに，リードタイム別の予測精 
度と計算時間について粒子フィルターを適用した場合と 比較を行い，カルマンフィルターの有用性を考察する.

\section{2. カルマンフィルターの定式化}

式(1)〜(4)で表されるUSFモデルによる河川流出量 $Q$ の 計算は次のように行う. 式(5), (6)の変数変換によって 式(1) (3) 加得られる連立常微分方程式を数值的に解 くことで $Q$ と $q_{R}$ の合計值を算定し, 式(4)より $q_{R}$ を求め $Q$ を得る.

$$
\begin{gathered}
s=k_{1}\left(Q+q_{R}\right)^{p_{1}}+k_{2}(d / d t)\left(Q+q_{R}\right)^{p_{2}} \\
d s / d t=R+I-E-O-Q-q_{R}-q_{l} \\
q_{l}= \begin{cases}k_{3}(s-z) & (s \geqq z) \\
0 & (s<z)\end{cases} \\
q_{R}= \begin{cases}\alpha\left(Q+q_{R}-Q_{o}\right) & \left(\alpha\left(Q+q_{R}-Q_{o}\right)<q_{R \max }\right) \\
q_{R}=q_{R \max } & \left(\alpha\left(Q+q_{R}-Q_{o}\right) \geqq q_{R \max }\right)\end{cases}
\end{gathered}
$$

ここに, $s$ : 総貯留高 $(\mathrm{mm}), t$ : 時間 $(\mathrm{min}), R$ : 降水量 $(\mathrm{mm} / \mathrm{min}), Q$ : 河川流出量 $(\mathrm{mm} / \mathrm{min}), q_{R}$ : 合流式下水道 による流域外への雨水排水量 $(\mathrm{mm} / \mathrm{min}), q_{R \max }$ : 最大雨水 排水量 $(\mathrm{mm} / \mathrm{min}), q_{l}$ : 地下水関連損失量 $(\mathrm{mm} / \mathrm{min}), I$ : 都 市特有の流入量 - 流域外からの地下水流入 $(\mathrm{mm} / \mathrm{min})$, $E$ : 繁発散量 $(\mathrm{mm} / \mathrm{min}), O:$ 取水量 $(\mathrm{mm} / \mathrm{min}), Q o:$ 初 期河川流出量 $(\mathrm{mm} / \mathrm{min}), \alpha$ : 下水道排出係数, $z$ : 浸透 孔高(mm), $k_{1}, k_{2}, k_{3}, p_{1}, p_{2}$ : モデルパラメータ.

式(5)，(6)の変数変換を行うことで， $x_{2}$ に関する一階の 常微分方程式が式(7a)のように得られる. なお, $s<z$ の ときは式(7b)となる.

$$
\begin{gathered}
x_{1}=\left(Q+q_{R}\right)^{p_{2}} \\
x_{2}=(d / d t)\left(Q+q_{R}\right)^{p_{2}} \\
\left\{\begin{array}{c}
d x_{2} / d t=-\left(k_{1} / k_{2}\right)\left(p_{1} / p_{2}\right) x_{1}{ }^{\left(p_{1} / p_{2}-1\right)} x_{2}-\left(1 / k_{2}\right) x_{1}{ }^{\left(1 / p_{2}\right)} \\
-\left(k_{1} k_{3} / k_{2}\right) x_{1}{ }^{\left(p_{1} / p_{2}\right)}-k_{3} x_{2} \\
+\left(1 / k_{2}\right)\left(R+I-E-O+k_{3} z\right) \\
d x_{2} / d t=-\left(k_{1} / k_{2}\right)\left(p_{1} / p_{2}\right) x_{1}{ }^{\left(p_{1} / p_{2}-1\right)} x_{2}-\left(1 / k_{2}\right) x_{1}{ }^{\left(1 / p_{2}\right)} \\
+\left(1 / k_{2}\right)(R+I-E-O)
\end{array}\right.
\end{gathered}
$$

カルマンフィルターの基礎式であるシステム方程式は 式(8), 観測方程式は式(9)で表される.

$$
\begin{gathered}
x(k+1)=\Phi(k) x(k)+\alpha(k)+u(k) \\
y(k)=\Gamma(k) x(k)+\beta(k)+w(k)
\end{gathered}
$$

ここに, $k$ : 時点, $x$ : システムの状態量ベクトル, $\Phi$ : 既知の状態遷移ベクトル， $\alpha$ : 既知のシステム定数ベク トル, $u$ : システム雑音, $y$ : 観測量ベクトル, $\Gamma$ : 既知 の観測行列, $\beta$ : 既知の観測定数ベクトル, $w$ : 観測雑 音.

USFモデルを用いたカルマンフィルターによる洪水流 出の実時間予測では, 推定すべき状態量として式(5),

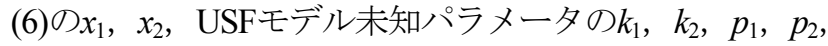
$k_{3}, z, a$ の他に $q_{R}$ を加えることで, 全ての未知パラ メータを組み込むことが可能になる.

$x_{3}=k_{1}, x_{4}=1 / k_{2}, \quad x_{5}=p_{1}, \quad x_{6}=1 / p_{2}, \quad x_{7}=k_{3}, \quad x_{8}=z, \quad x_{9}=\alpha$, $x_{10}=q_{R}$ とおくと, $\alpha\left(Q+q_{R}-Q_{o}\right)<q_{R \text { max }}$ の場合に $q_{R}$ は式 (10a)のように表され， $\alpha\left(Q+q_{R}-Q_{o}\right) \geqq q_{R \max }$ の場合は 式(10b)のように表される.

$$
\begin{gathered}
q_{R}=x_{10}=x_{9}\left(x_{1}^{x_{6}}-Q_{o}\right) \\
q_{R}=x_{10}=q_{R \max }
\end{gathered}
$$

ベクトル $X=\left[x_{1}, x_{2}, x_{3}, x_{4}, x_{5}, x_{6}, x_{7}, x_{8}, x_{9}, x_{10}\right]^{\mathrm{T}} \quad{ }^{\mathrm{T}}:$ 行列の転 置を表す）とおくと，式(7)の微分方程式は式(11)のよう に拡張される.

$d X(t) / d t=F(X)$

$$
\begin{aligned}
& =\left[\begin{array}{llllllllll}
f_{1} & f_{2} & 0 & 0 & 0 & 0 & 0 & 0 & 0 & f_{10}
\end{array}\right]^{T} \\
& f_{1}=x_{2} \\
& f_{2}=-x_{2} x_{3} x_{4} x_{5} x_{6} x_{1}{ }^{x_{5} x_{6}-1}-x_{4} x_{1}^{x_{6}}-x_{3} x_{4} x_{7} x_{1}^{x_{5} x_{6}} \\
& \quad-x_{2} x_{7}+x_{4}(R+I-E-O)+x_{4} x_{7} x_{8} \quad(s \geqq z) \\
& f_{2}=-x_{2} x_{3} x_{4} x_{5} x_{6} x_{1}{ }^{x_{5} x_{6}-1}-x_{4} x_{1}^{x_{6}}+x_{4}(R+I-E-O)
\end{aligned}
$$

$$
f_{10}=x_{2} x_{6} x_{1}^{x_{6}-1}-x_{2} x_{6} x_{9} x_{1}^{x_{6-1}}
$$

$$
\left(\alpha\left(Q+q_{R}-Q_{o}\right)<q_{R \max }\right)
$$

$f_{10}=x_{2} x_{6} x_{1}^{x_{6}-1}$ $\left(\alpha\left(Q+q_{R}-Q_{o}\right) \geqq q_{R \max }\right)$

ここで，カルマンフィルターの適用に便利なように式 (11)を線形化方程式に変換する. $F(X)$ をあらかじめ既知 な $X=X^{*}$ を中心するTaylor展開を行い，二次項以下を無 視して線形化すると式(12)となる.

$$
F(X)=A\left(X^{*}\right) X+B\left(X^{*}\right)
$$

ここに, 行列 $A\left(X^{*}\right)$ はJacobianであり, 行列 $B\left(X^{*}\right)$ は式 (13) で表される.

$$
B\left(X^{*}\right)=F\left(X^{*}\right)-A\left(X^{*}\right) X^{*}
$$

コンピュータを用いた計算が容易に行えるように式 (13)を式(14)の差分方程式に変換する.

$$
X(k+1)=\Psi(k) X(k)+\Lambda(k) B(k)
$$

ここに，kは離散化された計算時点であり，行列 $\Psi(k)$ は 式(15), $\Lambda(k)$ は式(16)で計算される.

$$
\begin{aligned}
\Psi(k) & =\exp (A \Delta t) \\
& \Leftrightarrow I+A \Delta t+(A \Delta t)^{2} / 2 !+(A \Delta t)^{3} / 3 !+(A \Delta t)^{4} / 4 !+\cdots \\
\Lambda(k) & =[\exp (A \Delta t)-I] A^{-1} \\
& =\Delta t\left[I+(A \Delta t) / 2 !+(A \Delta t)^{2} / 3 !+(A \Delta t)^{3} / 4 !+\cdots\right]
\end{aligned}
$$

ここに, $\Delta t:$ 計算時間間隔

以上により, カルマンフィルターのシステム方程式(8)の 状態量ベクトル $x$, 遷移行列 $\Phi(k)$, 定数ベクトル $\alpha(k)$ は，それぞれ式(14)のベクトル $X, \Psi(k), A(k) B(k)$ に対 応する.

$\alpha\left(Q+q_{R}-Q_{o}\right)<q_{R \max }$ の場合, カルマンフィルター の観測方程式(9)中の観測量ベクトル $y(k)$ は次式で表さ れる。

$$
y(k)=x_{1}{ }^{x_{6}}-x_{9} x_{1}{ }^{x_{6}}+x_{9} Q_{o}
$$

ここで, 非線型関数 $g(X)=y(k)$ で定義し, システム方 程式を定式化した場合と同様に線形化すると次式となる。

$$
g(X)=C\left(X^{*}\right) X+D\left(X^{*}\right)
$$

ただし， 


$$
\begin{aligned}
C\left(X^{*}\right) & \\
= & {\left[\begin{array}{llllllllll}
c_{1} & 0 & 0 & 0 & 0 & c_{6} & 0 & 0 & c_{9} & 0
\end{array}\right]^{T} X=X^{*} } \\
c_{1} & =x_{6} x_{1}^{x_{6}-1}-x_{6} x_{9} x_{1}^{x_{6}-1} \\
c_{6} & =x_{1}{ }^{x_{6}} \log x_{1}-x_{9} x_{1}^{x_{6}} \log x_{1} \\
c_{9} & =-x_{1}^{x_{6}}+Q_{o} \\
D(X) & =\left[x_{1}^{x_{6}}-x_{6} x_{1}{ }^{x_{6}}+x_{6} x_{9} x_{1}{ }^{x_{6}}-x_{6} x_{1}{ }^{x_{6}} \log x_{1}\right. \\
& \left.+x_{6} x_{9} x_{1}{ }^{x_{6}} \log x_{1}\right]_{X=X^{*}}
\end{aligned}
$$
$\alpha\left(Q+q_{R}-Q_{o}\right) \geqq q_{R \max }$ の場合，観測量ベクトル $y(k), C\left(X^{*}\right), D(X)$ は次式で表される.

$$
y(k)=x_{1}{ }^{x_{6}}-q_{R \max }
$$

$C\left(X^{*}\right)$

$$
\begin{aligned}
= & {\left[\begin{array}{llllllllll}
c_{1} & 0 & 0 & 0 & 0 & c_{6} & 0 & 0 & 0 & 0
\end{array}\right]^{T} X=X^{*} } \\
c_{1} & =x_{6} x_{1}{ }^{x_{6}-1} \\
c_{6} & =x_{1}{ }^{x_{6}} \log x_{1} \\
D(X) & =\left[x_{1}{ }^{x_{6}}-q_{R \max }-x_{6} x_{1}{ }^{x_{6}}-x_{6} x_{1}{ }^{x_{6}} \log x_{1}\right]_{X=X^{*}}
\end{aligned}
$$

以上により，カルマンフィルターのシステム方程式(9)の 観測量ベクトル $y(k)$, 観測行列 $\Gamma(k)$ ，定数ベクトル $\beta(k)$ は，それぞれ式(18)の $g(X), C\left(X^{*}\right), D\left(X^{*}\right)$ に対 応する。

\section{3. 仮想流域における検証}

\section{(1) 計算条件}

実時間予測特性を明らかにするため降雨流出特性が USFモデルによるパラメータによって与えられる仮想流 域を対象とする．東京の都市中小河川，神田川における 検討事例 ${ }^{7}$ を参考にモデルパラメータの真值は $k_{1}=50$, $k_{2}=500, k_{3}=0.005, \quad p_{1}=0.5, \quad p_{2}=0.5, \quad z=5, \quad \alpha=0.5, \quad q_{\text {Rmax }}=$ $0.05 \mathrm{~mm} / \mathrm{min}$ とする.

模擬発生させる雨量は，式(21)の降雨強度式を用いて 180分まで1分毎に降雨継続時間 $T$ (分) に対応する雨量を 算出し，これを2つ接続し360分間の降雨波形とする.

$$
r=700 /\left(T^{2 / 3}+8.0\right)
$$

模擬発生させる流出量は，USFモデルに模擬発生雨量 を入力してパラメータ真值を用いて流出量を算出したも のとする. USFモデルによる流出量の計算においては初 期河川流出量 $Q_{0}$ を $0.01 \mathrm{~mm} / \mathrm{min}$ とし, 雨量以外の流入成 分および蒸発散量はないものとする。また，実時間予測 計算で参照する流出量は真值流出量に観測雑音 $N(0$, $\left.0.01^{2}\right)$ を付加したものとし，これを観測流出量とする.

\section{（2）カルマンフィルターの適用}

USFモデルにカルマンフィルターを適用して実時間予 測特性を確認する．実際の洪水予測ではパラメータ真值 を知ることはできないので，ここでは表-1に示す4ケー スの值を初期パラメータ值とする．表中のパラメータ值 を固定して計算した場合のハイドログラフを模擬発生雨
量ハイエトグラフと共に図-1に示す。図中には各ケース の計算流出量について観測流出量に対するNash-Sutcliffe 指標(NSE)の值を記している. なお，予測流出量との比 較のため，1分先から60分先までの予測值がある降雨開 始後61〜360分をNSEの計算期間としており，以降に示 すNSEも同じ計算期間としている.

1分毎に観測流出量と雨量を参照しながらカルマン フィルターによってUSFモデルパラメータ $\left(k_{1}, k_{2}, p_{1}\right.$, $\left.p_{2}, k_{3}, z, \alpha\right)$ の值を更新しながら各時点において60分 先までの流出量を計算する.

カルマンフィルターによる実時間洪水流出予測に際し ては，推定すべき状態量の初期推定值 $\hat{x}(0 \mid 0)$ とその推 定誤差共分散行列 $P(0 \mid 0)$, システム杂隹音の共分散行列 $U(k)$ および観測雑音の共分散行列 $W(k)$ を設定する必 要があり ${ }^{10)}, U(k)$ の設定において $P(0 \mid 0)$ の対角要素に 対する倍率であるSNPERを入力し， $W(k)$ の設定におい て観測雑音の標準偏差 $S D W$ の力を行う。これらの設 定は以下のように行う。 $\hat{x}(0 \mid 0)$ については， $x_{1}$ を $Q_{o}{ }^{1 / p_{2}} ， x_{2}$ を $0, x_{3} \sim x_{9}$ を表-1より設定し， $x_{10}$ を 0 とする. $U(k)$ については, 非対角要素を 0 とし対角要素は $P(0 \mid 0)$ をSNPER倍したものとする。また，W(k) は $S D W^{2}$ とする. $P(0 \mid 0) の x_{1} \sim x_{10}, S N P E R, S D W の 12$ 項 目（以下， $K F$ 設定值）は，リードタイム10分，30分， 60分（以下，LT 10，LT30，LT60）の各々に対してより 観測值に近い予測值を出力する設定值を求める. また, $K F$ 設定值は，表-1に示したケース1〜4の各々に対する ものと全てのケースに対するものを求めることとし，そ の值の探索には大域的探索法であるSCE-UA法 ${ }^{11}$ を用い る. SCE-UA法はモデルパラメータの自動最適化におい て強力かつ効率的な手法であることが示されている ${ }^{12)}$. SCE-UA法の探索において誤差評価関数はNSEとし, 各 項目の探索範囲は0.001〜 1とする.

図-2にLT 10，LT 30，LT 60の $K F$ 設定值を示す. $L T$ 30 ・ケース 1 の $x_{8}$ やLT60・ケース4の $x_{6}, x_{10}$ のように同

\section{表-1＼cjkstart初期パラメータ}

\begin{tabular}{|c|c|c|c|c|c|c|c|}
\hline & $k_{1}$ & $k_{2}$ & $p_{1}$ & $p_{2}$ & $k_{3}$ & $z$ & $\alpha$ \\
\hline ケース1 & 30 & 300 & 0.3 & 0.3 & 0.003 & 3 & 0.3 \\
\hline ケース2 & 40 & 400 & 0.4 & 0.4 & 0.004 & 4 & 0.4 \\
\hline ケース3 & 60 & 600 & 0.6 & 0.6 & 0.006 & 6 & 0.6 \\
\hline ケース4 & 70 & 700 & 0.7 & 0.7 & 0.007 & 7 & 0.7 \\
\hline
\end{tabular}

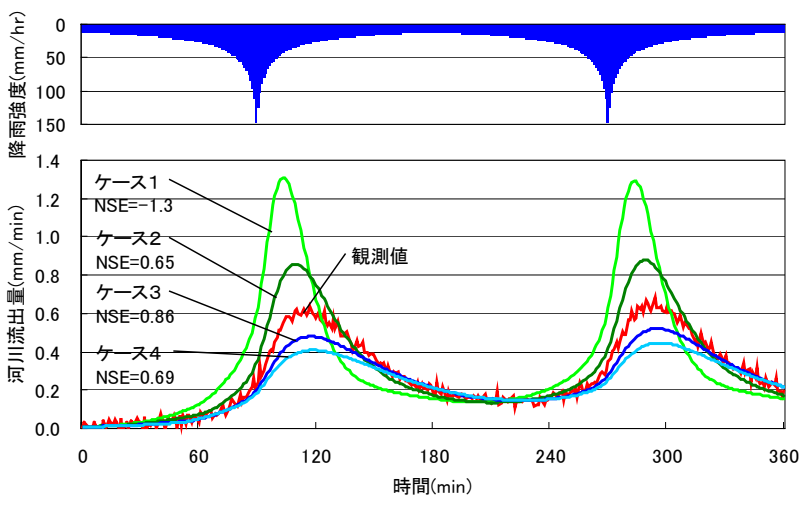

図-1＼cjkstart初期パラメータ固定による河川流出量 


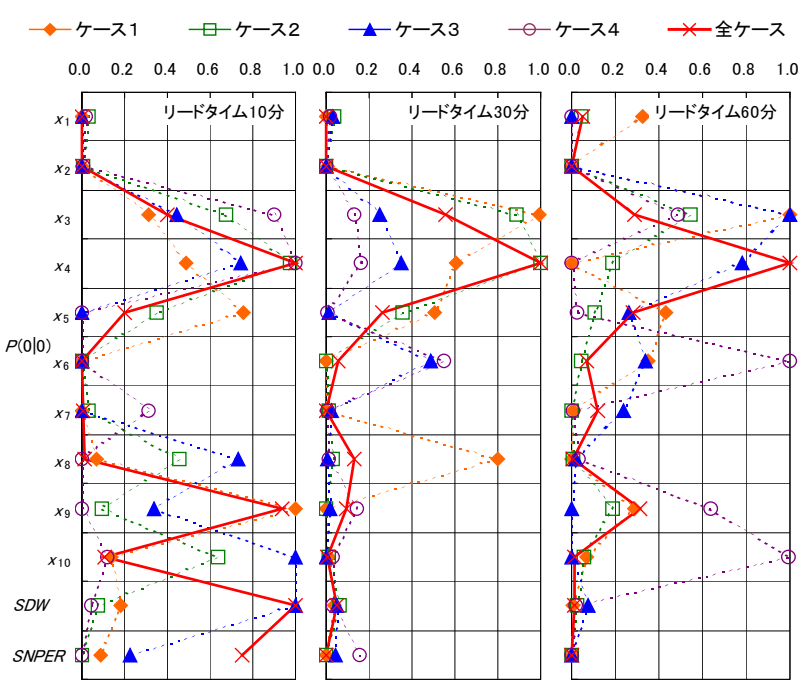

図-2 KF設定值

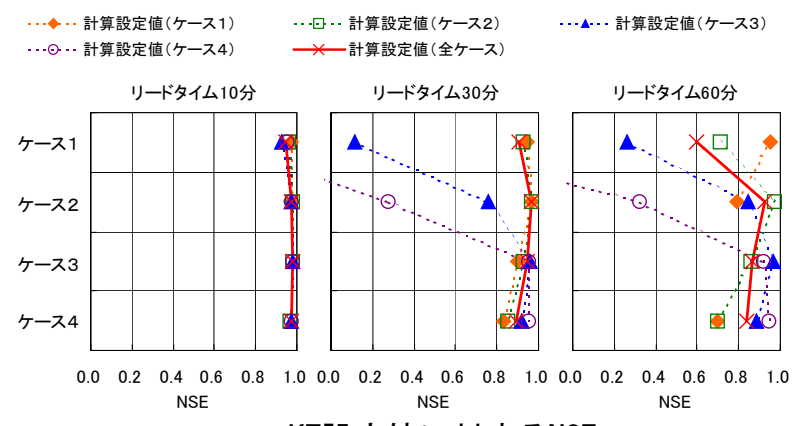

図-3ＫF設定值に対するNSE

じリードタイムであってもケースによって值が大きく異 なる項目がある. また, 全ケースに対する $K F$ 設定值は4 ケースの平均值とは大きく異なっており，例えば， $L T$ 10 の SNPER やLT 60 における $x_{4}$ はケース 1 ４の最大值 よりさらに大きな值となっている.

全ケースに対する $K F$ 設定值において 1 に近い項目は, $L T 10$ では $x_{4}, x_{9}, S D W, S N P E R の 4$ 項目であり，LT30と $L T 60$ では $x_{4}$ の1項目となっている. また，LT60の $x_{1}$ は $L T 10 や L T 30$ ののより大きな值となっている. リード タイムによって探索された $K F$ 設定值が異なっており, リードタイムに応じて適切な $K F$ 設定值を設定すること でリードタイムに拘らず予測精度の向上を図ることが可 能である.

図-3に図-2に示した $K F$ 設定值を用いて各ケースを計 算した時のNSEを示す．各々のケースに対する $K F$ 設定 值によるNSEは，LT10が0.97〜0.98，LT30が0.94〜0.97, LT 60が0.95 0.97といずれも1に極めて近い. 各々の計 算に適した $K F$ 設定值を与えることが可能であれば 60 分 先までの流出量を極めて高精度に算定することができる.

$L T 10$ NSEは図-2のいずれの $K F$ 設定值を選択しても 大きな違いはみられない.一方，LT30とLT60について はKF設定值によってNSEに違いがみられるＬLT30では ケース1と2および全ケースに対する $K F$ 設定值を選択し た場合の4ケースのNSEは0.8以上であるが，他を選択し

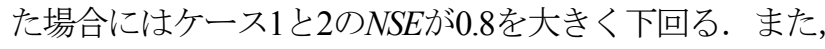
LT 60ではLT 30と同様の傾向が見られるが，いずれのKF
設定值を選択してもNSEが0.8を下回るケースがある.

リードタイムが10分程度の場合には良好な予測值を得 られる $K F$ 設定值の範囲が広いが，リードタイムが30分 程度になるとその範囲が限られるので $K F$ 設定值の設定 に際しては十分に検討を行うことが必要である.

図-4に全ケースに対する $K F$ 設定値による計算ハイド ログラフを示す．1つ目のピーク周辺の予測值はリード タイムによる違いがみられるが，2つ目のピーク周辺で はリードタイムに拘らす観測值に極めて近い予測值が得 られている. また, 1つ目のピークについても初期パラ メータ固定による計算と比べて予測精度が改善されてお り，NSEが0.8を下回るケース1のLT60についてもピーク 流出量が大幅に改善されている. カルマンフィルターを 適用した計算では予測值が短時間に大きく変化する傾向 がみられ, 特にケース 1 の L 600 2つ目のピーク付近で は大きな変化がみられる.

図-4の計算をした時のパラメータの時系列変化を図-5 に示す. $k_{1}, k_{2}, p_{1}$ は 3 種類のリードタイムに対して計
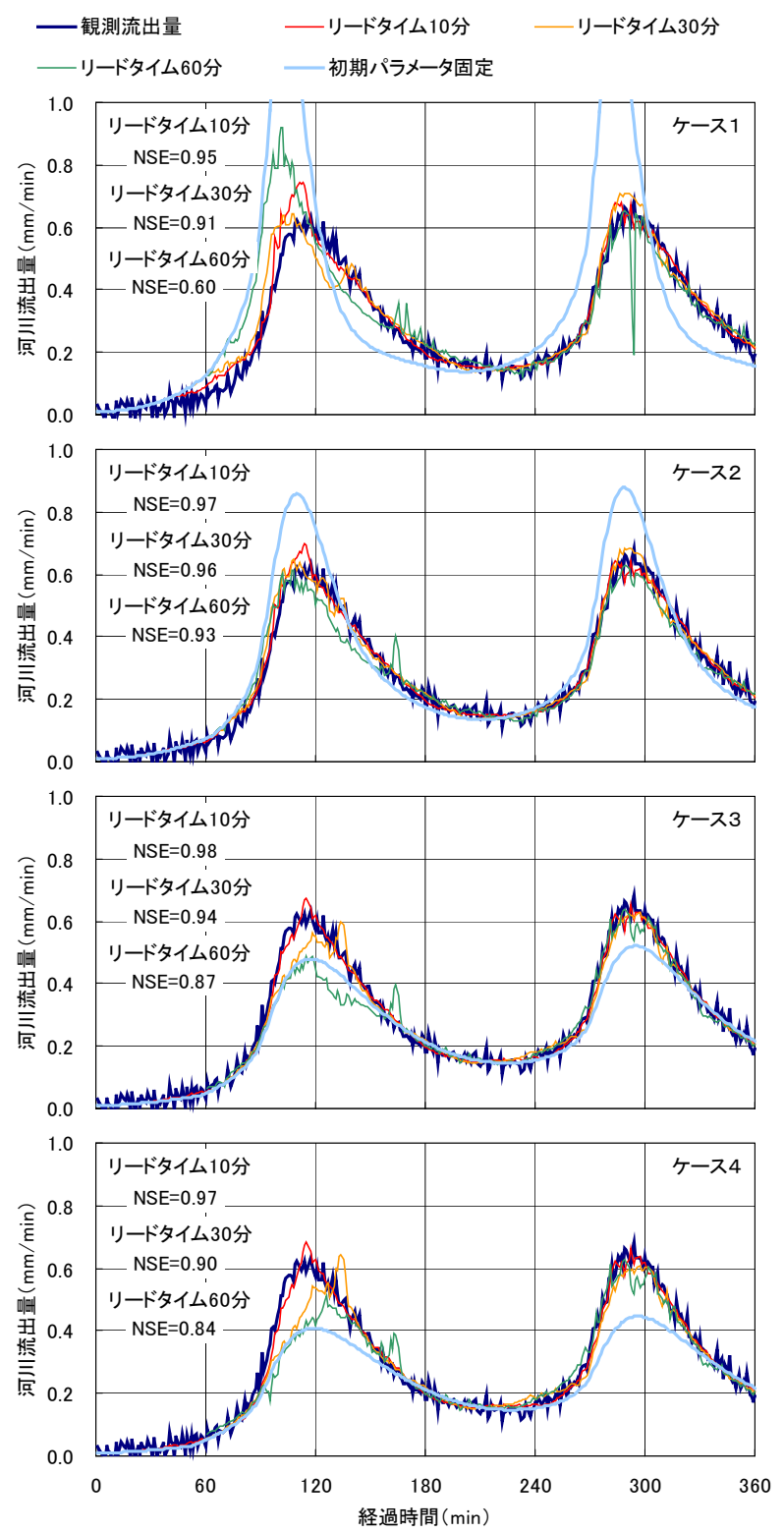

図-4カルマンフィルターによるハイドログラフ 


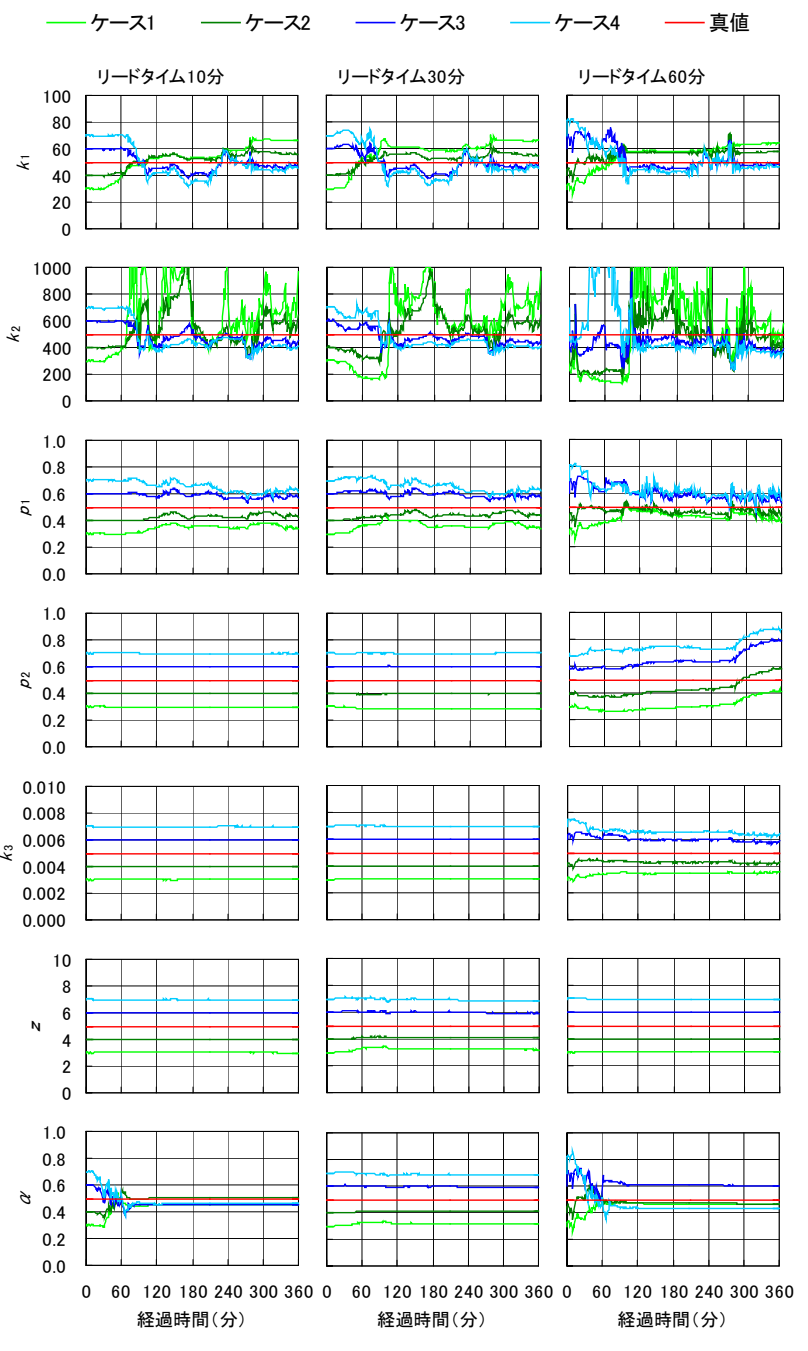

図-5 カルマンフィルターによるパラメータの変化

算期間を通じて変化がみられる。これらのパラメータは リードタイムが長くなると，パラメータ值の変化量が大 きくなる傾向がみられ，また，これらのパラメータ值が 大きく変化を始める時刻が早くなる. $p_{2}, k_{3}$ の值に大き な変化がみられるのはLT60のみである. $Z$ の值はリード タイムに拘らず大きな変化をしていない。これは $z$ が都 市流域の河川流出量について降雨終了後の低減部の再現 を目的として導入されたパラメータであり，本検討にお いては流出量が比較的大きい状況で計算期間が終了して いるため， $Z$ が流出量の計算に大きな影響を及ぼさな かったものと考えられる．LT 10 とLT60の $\alpha$ の変化は計 算開始から120分経過時より前までとなっている. これ は $\alpha$ が流出量の計算に寄与するのが式(4)より $q_{R}$ が $q_{R \max }$ よ り小さい期間のみであり, $q_{R}$ が120分経過時点で $q_{R \max }$ に 達していることがその原因であると考えられる.

\section{（3）カルマンフィルターと粒子フィルターの比較}

カルマンフィルターと粒子フィルターの実時間予測特 性を比較する. 粒子フィルターの計算は, カルマンフィ ルターと同様に1分毎に観測流出量と雨量を参照しなが らUSFモデルの未知パラメータ $k_{1}, k_{2}, k_{3}, p_{1}, p_{2}, z, \alpha$ の值 を更新しながら各時点において 60 分先までの流出量を計
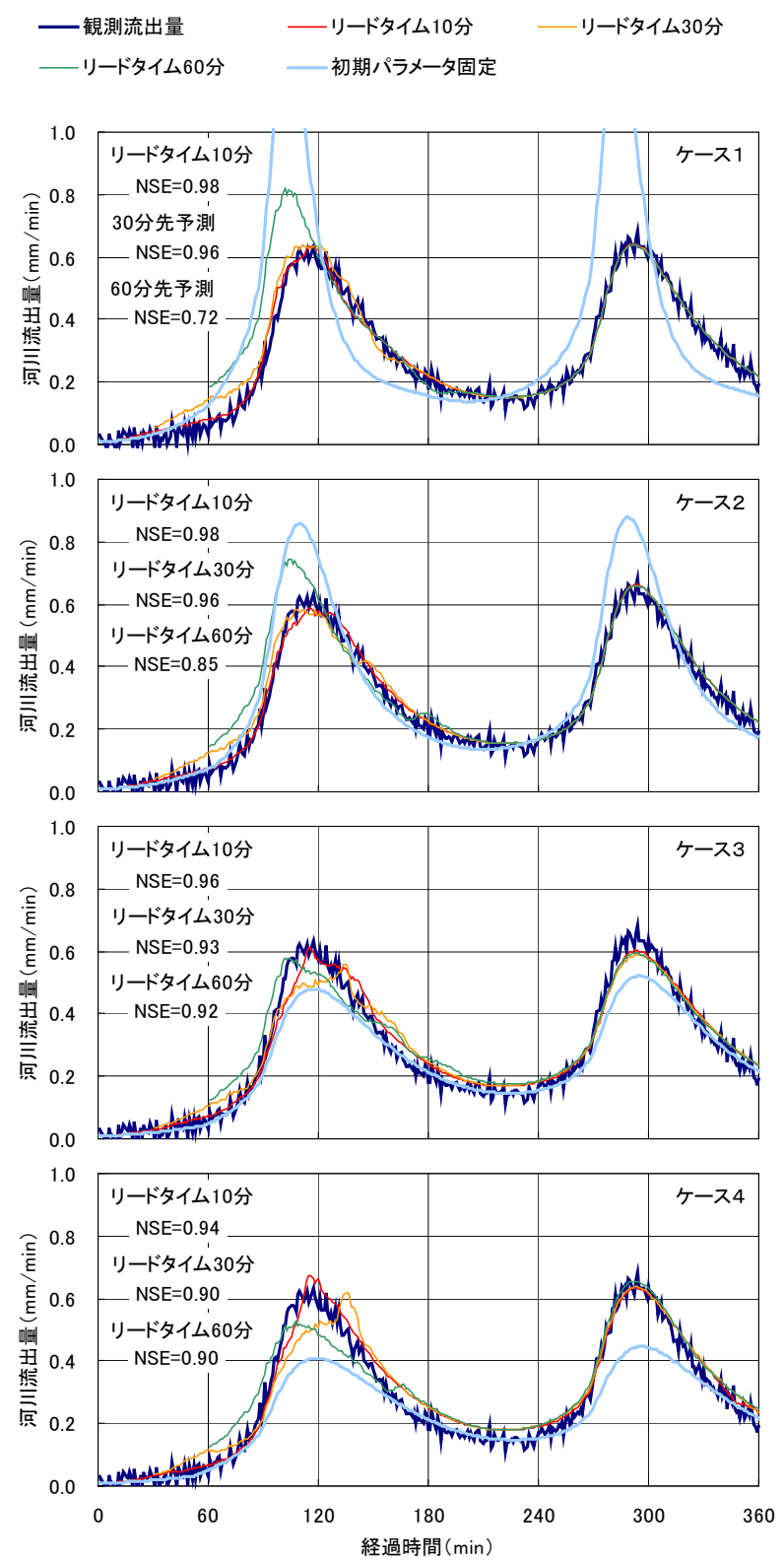

図-6＼cjkstart粒子フィルターによるハイドログラフ

算する. USFモデルへの粒子フィルターの適用について は既に検討しており ${ }^{8)}$ ，良好な予測結果を得られる以下 の設定によって計算を行う. 粒子が保持する情報はUSF モデルパラメータに状態量 $x_{1}, x_{2}$ を加えた状態量ベクト ル $X=\left[k_{1}, k_{2}, k_{3}, p_{1}, p_{2}, z, \alpha, x_{1}, x_{2}\right]$ とする. 粒子数は 10000 個とし，各粒子が保持するパラメータは，表-1に示した 初期パラメータ值 $\mu$ に対して $N\left(\mu, \mu^{2}\right)$ によって発生させ たものとし， $x_{1}$ は $Q_{o}{ }^{1 / p_{2}}$ とし， $x_{2}$ は0とする. システム ノイズは各粒子が保持するパラメータの $0.1 \%$ する。 な お，粒子フィルターの設定はリードタイムに拘らず1種 類とする.

粒子フィルターによって河川流出量を計算した結果を 図-6に示す. 図-4に示したカルマンフィルターによる八 イドログラフと似たものとなっている. カルマンフィル ターにみられた予測值が短時間に大きく変化する傾向が みられなくなっている．NSEを比べるとリードタイムや ケースによってカルマンフィルターが良好な場合と粒子 


\section{表-2 計算時間}

\begin{tabular}{|c|c|c|c|c|c|}
\hline \multirow{2}{*}{} & \multicolumn{2}{|c|}{ 1ケースの計算時間 } & \multicolumn{2}{|c|}{ 1時点あたりの計算時間 } & \multirow{2}{*}{ 比率 } \\
\cline { 2 - 5 } & カルマンフルター & 粒子フィルター & カルマンフィルター & 粒子フィルター & \\
\hline PC1 & 0.639 秒 & 1377.966 秒 & 0.002 秒 & 4.59秒 & 2156 \\
\hline PC2 & 0.422 秒 & 1332.453 秒 & 0.001 秒 & 4.44 秒 & 3157 \\
\hline
\end{tabular}

PC2: CPU AMD PhenomII X6 1090T 3.2GHz, RAM2.7GB

フィルターが良好な場合があり，全体的に見ると概ね同 等であると判断された.

表-2にUSFモデルにカルマンフィルターおよび粒子 フィルターを適用して1ケースの計算に要した時間を示 す. 表中の比率はカルマンフィルターの計算時間を 1 と した時の粒子フィルターの計算時間を示している．粒子 フィルターについては並列処理による高速化が可能であ るが本検討では行っていない.

PC環境によって異なるもののカルマンフィルターの 計算時間は粒子フィルターの概ね $1 / 2000 １ / 3000$ であり, カルマンフィルターを適用しリードタイム 1 分毎に異な る $K F$ 設定值を用いて 60 分先までの計算を行った場合で も粒子フィルターを適用する場合より短時間に計算が終 了する.

1ケースの計算では経過時間360分までの計算を行って いることから，60分先までの予測計算を行う期間を考慮 し，1ケースの計算時間を300で割ったものを1時点あた りの計算時間として表中に示した。1地点のみを対象と した場合には，1時点あたりの計算に要する時間は5秒以 下であり，1分間隔で水文データを取得して計算を行う ことを考えると計算時間の点では問題ないと考えられる。 しかし, 複数地点を対象とする場合や水文データ取得の 処理に時間を要する場合には，より短時間に計算を行う ことが求められ，並列処理等の高速化が必要になる．な お，計算機資源に大きな制約を受ける場合は粒子フィル ターの適用は難しいのでカルマンフィルターを適用する ことになる.

\section{4. まとめ}

USFモデルへのカルマンフィルターを適用するために 定式化を行った. 定式化に際しては1変数の追加により カルマンフィルターが全ての未知パラメータを取り扱え るようにした。 そして，降雨流出特性が既知の仮想流域 を対象に，カルマンフィルターを適用したUSFモデルの 実時間予測特性について検証を行った，以下に本検証の 結果を記す。

USFモデルにカルマンフィルターまたは粒子フィル ターを適用することによってパラメータを固定した計算 と比較して，60分先までの計算流出量の予測精度が向上 した. USFモデルにカルマンフィルターを適用した場合, $K F$ 設定值によって予測精度が大きく変化するので，そ の設定においては十分な検討が必要である。また，リー ドタイム毎に適切な $K F$ 設定值を用いることで予測精度 が向上し，粒子フィルターと変わらない予測精度を得る ことができた. カルマンフィルターは計算時間が極めて 短く，リードタイム別に異なる計算を行っても粒子フィ ルターより計算を短時間に終了させた。
粒子フィルターは十分に多くの粒子数を用いることに よって1種類の設定のみでリードタイムに拘らず高い予 測精度を得られ，さらに，カルマンフィルターでみられ た短時間の大きな予測值の変化がない利点が確認された. 一方で多くの粒子数を用いることによってカルマンフィ ルターと比べ大幅に長い計算時間を要する.

カルマンフィルターと粒子フィルターは予測精度の改 善程度に大きな違いが見られなかったことから，計算機 資源に余裕のある場合には取り扱いが容易な粒子フィル ターを採用し，そうでない場合にはカルマンフィルター を用いるといった使い分けが考えられる.

\section{参考文献}

1) 東京都 : 東京都地下空間浸水対策ガイドライン一地下空間 を水害から守るために一: p4,2008.

2) 独立行政法人土木研究所・寒地土木研究所寒地河川チー ム : 対話式洪水予測計算マニュアル，財団法人北海道河川防 災研究センター・研究所, 2006.

3) 工藤亮治, 近森秀高, 永井明博 : 粒子フィルタを用いた河 川流域における実時間洪水予測, 農業農村工学会論文集, No.259, pp.17-25, 2009.

4) 立川康人, 須藤純一, 椎葉充晴, 萬和明, キムスンミン: 粒子フィルタを用いた河川水位の実時間予測手法の開発，水 工学論文集，第55巻, pp.S 511-S 516, 2011.

5) 高橋正樹, 藤井真人, 柴田正啓, 八木伸行 : ゴルフ中継で の放送カメラを用いたティーショット軌道表示システム，電 子情報通信学会論文誌，D，Vol. J92-D, No.7, pp.1036-1044， 2009.

6) 宍戸英彦, 北原格, 亀田能成, 大田友一 : パーティクル フィルタとカルマンフィルタを補完的に利用したバドミント ン映像からのシャトル軌道推定, 動的画像処理実用化ワーク ショップ DIA2012, pp.206-211,2012.

7) 高崎忠勝, 河村明, 天口英雄 : 都市の流出機構を考慮した 新たな貯留関数モデルの提案, 土木学会論文集B, Vol.65, No.3, pp.217-230, 2009.

8) 高崎忠勝, 河村明, 天口英雄, 石原成幸 : 粒子フィルタを 用いた都市貯留関数モデルによる実時間洪水流出予測特性, 土木学会論文集B1(水工学) Vol.68, No.4, I_511-I_516, 2012.

9) 高野晃平, 河村明, 高崎忠勝, 天口英雄, 中川直子 : エ リート戦略を用いた粒子フィルタによるUSFモデルの実時間 流出予測特性，第39回土木学会関東支部技術研究発表会, II $-39,2012$.

10) 河村明 : 貯留関数法を用いたカルマンフィルターによる洪 水流出の実時間予測，水理公式集例題プログラム集CD-ROM 版, 土木学会,pp1.12.1-1.12.26, 2001.

11) Duan Q, Sorooshian S, Gupta VK. : Effective and Efficient Global Optimization for Conceptual Rainfall-Runoff Models, Water Resources Research, 28-4: 1015-1031， 1992.

12) 田中丸治哉 : タンクモデル定数の大域的探索, 農業土木学 会論文集 No.178, pp.103-112，1995.

(2012.9.30受付) 